\title{
Preparation of SBS Modified Emulsified Asphalt in High Cold Region
}

\author{
HOU Yanming \\ College of Civil Engineering, Nanjing Forestry University,Nanjing,Jiangsu 210037,China
}

\begin{abstract}
A kind of SBS modified emulsified asphalt for highly cold area was studied by experiments. The research includes two aspects: the first is preparation of SBS modified asphalt. The influence of temperature, time, shear rate and development time on asphalt modification are determined, so as to determine the process of SBS modified asphalt. On this basis, the blending ratio of SBS modified emulsified asphalt was determined by experiments. The results show that the emulsified asphalt produced by the equipment is of good quality and good ductility.4\%SBS latex content can make emulsified asphalt meet the standard requirements, but only $6 \%$ SBS latex content can obtain better road performance. Although the softening point of SBS modified emulsified asphalt prepared by this method is still low, it can meet the requirements of high cold area.
\end{abstract}

\section{Introduction}

SBS modified emulsified asphalt has the advantages of high and low temperature performance, strong resilience, strong cohesion, good crack resistance and wide application area, so it has a good application prospect. At present, the main factors affecting the SBS modified emulsified asphalt are as follows: (1) Modification of asphalt: including the type of base asphalt, SBS modifier varieties, dosage, blending process, stabilizer varieties and SBS particle shear fineness and other factors; (2) Selection of emulsifier: Including the variety and dosage of emulsifier, the variety and dosage of stabilizer and other factors; (3) Selection of emulsified asphalt production equipment and production process and so on ${ }^{[1-5]}$. In view of this, it is undoubtedly important to develop SBS modified emulsified asphalt for high-grade highway pavement in alpine region by optimizing material compatibility and fine quality control.

Based on the above considerations, the SBS modified emulsified asphalt suitable for climatic environment in alpine region was developed through a large number of experiments in this study ${ }^{[6-10]}$.

\section{Preparation technology of SBS modified asphalt}

In this experiment, the softening point and ductility index at $5^{\circ} \mathrm{C}$ of SK90 matrix asphalt after modification were taken as the evaluation indexes. The technological conditions such as shear temperature, shear time, shear rate and development time were analyzed, and the reasonable and optimized technological conditions were finally determined.

Modified asphalt was prepared from L4RT colloid mill produced by Silveson company.

\subsection{Effect of shear temperature}

The effect of shear temperature on the performance of modified asphalt is shown in Table 1. The experimental conditions are as follows: the shear time is $1 \mathrm{~h}$, the shear rate is $3000 \mathrm{rpm}$, the shear temperature is $160^{\circ} \mathrm{C}$, and the addition of modifier and stabilizer is $3 \%$ and $0.265 \%$ (quality ratio with asphalt).

Table 1 Effect of shear temperature on properties of modified asphalt

\begin{tabular}{ccccc}
\hline Shear temperature $/{ }^{\circ} \mathrm{C}$ & $\mathbf{1 6 5}$ & $\mathbf{1 7 5}$ & $\mathbf{1 8 5}$ & $\mathbf{1 9 5}$ \\
\hline $5^{\circ} \mathrm{C}$ Ductility $/ \mathrm{cm}$ & 0 & 30 & 25 & 0 \\
$25^{\circ} \mathrm{C}$ Needle penetration $/ 0.1 \mathrm{~mm}$ & 42 & 50 & 44 & 40 \\
Softening point $/{ }^{\circ} \mathrm{C}$ & 61 & 60 & 58 & 57 \\
\hline
\end{tabular}

Table 1 shows that the softening point of the modified asphalt changes smoothly first and then decreases slightly with the increase of shear temperature. The modified asphalt samples prepared at $165^{\circ} \mathrm{C}$ and $195^{\circ} \mathrm{C}$ have brittle fracture when the ductility index at $5^{\circ} \mathrm{C}$ is measured, and their plastic deformation is very poor. By comprehensive analysis, the shear temperature is determined to be $175^{\circ} \mathrm{C}$.

\subsection{Effect of shear time}


The effect of shear time on the performance of modified asphalt is shown in Table 2. The experimental conditions are as follows: the shear temperature is $175^{\circ} \mathrm{C}$, the shear rate is $3000 \mathrm{rpm}$, and the growth time is $1 \mathrm{~h}$ at $160{ }^{\circ} \mathrm{C}$. The addition of modifier and stabilizer is $3 \%$ and $0.265 \%$ respectively.

Considering that the alpine region should be dominated by low temperature indicators, the shear time is $60 \mathrm{~min}$.

Table 2 Effect of shear time on properties of modified asphalt

\begin{tabular}{ccccc}
\hline Shear time $/ \mathbf{m i n}$ & $\mathbf{3 0}$ & $\mathbf{6 0}$ & $\mathbf{9 0}$ & $\mathbf{1 2 0}$ \\
\hline $5^{\circ} \mathrm{C}$ Ductility $/ \mathrm{cm}$ & 17 & 30 & 18 & 20 \\
$25^{\circ} \mathrm{C}$ Needle penetration & 46 & 52 & 50 & 52 \\
$\begin{array}{c}/ 0.1 \mathrm{~mm} \\
\text { Softening point } /{ }^{\circ} \mathrm{C}\end{array}$ & 70 & 60 & 60 & 58 \\
\hline
\end{tabular}

\subsection{Effect of shear rate}

The effect of shear rate on the performance of modified asphalt is shown in Table 3 . The experimental conditions are as follows: the shear temperature is $175^{\circ} \mathrm{C}$, and the sample is put into $160{ }^{\circ} \mathrm{C}$ oven for $1 \mathrm{~h}$ after shearing for $1 \mathrm{~h}$. The addition of modifier and stabilizer is $3 \%$ and $0.265 \%$ respectively.

From table 3, it can be seen that with the increase of shear rate, the index of modified asphalt increases first and then decreases; when the shear rate is $3000 \mathrm{rpm}$, the softening point and ductility of modified asphalt are the largest, and its high and low temperature performance is better.

Based on the above analysis, the shear rate is determined to be 3000rpm.

Table 3 Effect of shear rate on properties of modified asphalt

\begin{tabular}{ccccc}
\hline Shear rate $/$ min & $\mathbf{1 0 0 0}$ & $\mathbf{3 0 0 0}$ & $\mathbf{5 0 0 0}$ & $\mathbf{7 0 0 0}$ \\
\hline $5^{\circ} \mathrm{C}$ Ductility $/ \mathrm{cm}$ & 12 & 28 & 25 & 18 \\
$25^{\circ} \mathrm{C}$ Needle penetration & 48 & 50 & 78 & 55 \\
$/ 0.1 \mathrm{~mm}$ & & & & \\
Softening point $/{ }^{\circ} \mathrm{C}$ & 55 & 62 & 54 & 51 \\
\hline
\end{tabular}

\subsection{Development time}

The effect of growth time on the performance of modified asphalt is shown in Table 4. The experimental conditions are as follows: the shear temperature is $175^{\circ} \mathrm{C}$, the shear rate is $3000 \mathrm{rpm}$, and the shear rate develops at $160^{\circ} \mathrm{C}$ after $1 \mathrm{~h}$. The addition of modifier and stabilizer is $3 \%$ and $0.265 \%$ respectively. Comprehensive analysis confirmed that the developmental time was $1 \mathrm{~h}$.

Table 4 Effect of development time on properties of modified asphalt

\begin{tabular}{ccccc}
\hline Development time $/ \mathbf{h}$ & $\mathbf{1}$ & $\mathbf{2}$ & $\mathbf{3}$ & $\mathbf{4}$ \\
\hline $5^{\circ} \mathrm{CDuctility} / \mathrm{cm}$ & 30 & 21 & 21 & 25 \\
$25^{\circ} \mathrm{C}$ Needle penetration $/ 0.1 \mathrm{~mm}$ & 53 & 51 & 50 & 52 \\
Softening point $/{ }^{\circ} \mathrm{C}$ & 62 & 60 & 60 & 59 \\
\hline
\end{tabular}

Through the above investigation of the preparation process conditions of modified asphalt, and drawing lessons from the asphalt modification process proposed by other researchers [6-10]. The preparation process of modified asphalt is determined as follows: heating the base asphalt and maintaining its temperature at about $175^{\circ} \mathrm{C}$. The solid SBS modifier and stabilizer are added under the high speed shearing of $3000 \mathrm{rpm}$ shearing machine. At the same time, the samples were slowly added to the hot asphalt. After shearing for about $1 \mathrm{~h}$, the samples were placed in the oven at $16^{\circ} \mathrm{C}$ for $1 \mathrm{~h}$ to develop. Then the samples were retained to determine their properties and then the samples were emulsified.

\section{Peparation of SBS modified asphalt}

\subsection{Main raw materials}

1) asphalt: in this experiment, SK90 matrix asphalt commonly used to produce emulsified asphalt was chosen. The three major indicators are shown in Table 5:

Table 5 The three major indicators of SK90\# asphalt

\begin{tabular}{ccc}
\hline Project & Unit & Index \\
\hline Softening point & ${ }^{\circ} \mathrm{C}$ & 46.7 \\
Needle penetration $\left(25^{\circ} \mathrm{C}\right)$ & $\mathrm{mm}$ & 94.7 \\
Ductility $\left(15^{\circ} \mathrm{C}\right)$ & $\mathrm{cm}$ & $>100$ \\
\hline
\end{tabular}

2) SBS: The modifier used in this test is YH-792 linear SBS produced by Yueyang baling Petrochemical Industries Company. The specific indexes are in Table 6.

Table 6 YH-792 Linear SBS performance indicators

\begin{tabular}{cc}
\hline Nature & YH-792 \\
\hline Structure & linear \\
Molecular mass & 100000 \\
Block ratio (S/B) & $40 / 60$ \\
Oil filling rate, \% & 0 \\
Tensile strength /MPa & $>18.0$ \\
Elongation, \% & $>600$ \\
Permanent deformation, \% & $<65$ \\
Hardness / (SHAO) & $>80$ \\
\hline
\end{tabular}

\subsection{Test results}

The performance of SBS modified asphalt with different SBS content is shown in Table 7.

Table 7 Test index of SBS modified asphalt

\begin{tabular}{lccccc}
\hline $\begin{array}{l}\text { K } \\
\text { aspha } \\
\text { lt }\end{array}$ & $\begin{array}{c}\mathrm{B} \\
\mathrm{S}\end{array}$ & $\begin{array}{c}\mathrm{ng} \\
\left({ }^{\circ} \mathrm{C}\right)\end{array}$ & $\begin{array}{c}\text { Softeni } \\
\text { point }\end{array}$ & $\begin{array}{c}5 \\
\text { Ductility } \\
(\mathrm{cm})\end{array}$ & $\begin{array}{c}{ }^{\circ} \mathrm{C} \\
\text { Ductility } \\
(\mathrm{cm})\end{array}$ \\
\hline 00 & 1 & & 47.8 & - & 57.5 \\
00 & 1 & 62.3 & 21.4 & 40 \\
00 & 1 & & 75.4 & 35 & 76 \\
00 & 1 & & 80.6 & 49.7 & $>100$ \\
\hline
\end{tabular}

\section{Preparation and performance test of SBS modified emulsified asphalt}

\subsection{Main raw materials}

1) asphalt: 3 kinds of SBS modified asphalt prepared above.

2) emulsifier: cationic emulsifier Peral600. 
3) stabilizer: The stability of the emulsion was increased by using PC1698 and methyl compound which were imported from inorganic stabilizer and organic stabilizer.

4) $\mathrm{pH}$ regulator: choose $35 \%$ concentrated hydrochloric acid as $\mathrm{pH}$ regulator.

5) SBS latex: technical indicators are shown in Table 8.

Table 8 SBS Latex technical specifications

\begin{tabular}{cc}
\hline Nature & SBS latex \\
\hline Ion charge & + \\
particle size, $\mu m$ & 1.97 \\
Particle size, $\%$ & 40.5 \\
$\mathrm{pH}$ & 2.72 \\
viscosity, $\mathrm{mPa} \cdot \mathrm{s}$ & 41 \\
Mechanical stability, \% & 0.38
\end{tabular}

\author{
Coagulant, \% \\ 0.009 \\ density, $20^{\circ} \mathrm{C}, \mathrm{g} / \mathrm{cm} 3$ \\ 0.9901
}

\subsection{Determination of the proportioning of emulsifiers}

On the basis of emulsifying formula provided by emulsifier manufacturer, taking the basic emulsifier Peral417 as the maximum value of $1.8 \%$ unchanged, changing the dosage of compound emulsifier Peral600, keeping the oil-water ratio, soap temperature, asphalt, emulsifying time and so on the same and unchanged, and the emulsifying effect of modified asphalt with $5 \%$ and $7 \%$ SBS content in different emulsifier ratios was investigated without other additives interference. The concrete test results were shown in Table 9.

Table 9 Effect of compound emulsifier on emulsifying effect

\begin{tabular}{|c|c|c|c|c|c|c|c|c|c|}
\hline Process & No. 0 & No. 1 & No. 2 & No. 3 & No. 4 & No. 5 & No. 6 & No. 7 & $\begin{array}{c}\text { technical } \\
\text { requirem } \\
\text { ent }\end{array}$ \\
\hline $\begin{array}{l}\text { Emulsifyi } \\
\text { ng effect }\end{array}$ & $\begin{array}{c}\text { Good } \\
\text { emulsificati } \\
\text { on effect }\end{array}$ & $\begin{array}{c}\text { Not } \\
\text { emulsifi } \\
\text { ed }\end{array}$ & $\begin{array}{c}\text { Emulsifiab } \\
\text { le and } \\
\text { crusting }\end{array}$ & $\begin{array}{c}\text { Emulsifia } \\
\text { ble and } \\
\text { crusting }\end{array}$ & $\begin{array}{c}\text { Emulsifia } \\
\text { ble }\end{array}$ & $\begin{array}{c}\text { Emulsifiab } \\
\text { le }\end{array}$ & $\begin{array}{c}\text { Emulsifia } \\
\text { ble }\end{array}$ & $\begin{array}{c}\text { Emulsifia } \\
\text { ble }\end{array}$ & \\
\hline $\begin{array}{l}\text { Particle } \\
\text { charge }\end{array}$ & + & - & + & + & + & + & + & + & + \\
\hline $\begin{array}{l}\text { Residue } \\
\text { on sieve }\end{array}$ & 0.02 & - & 4.0 & 3.8 & 0.09 & 0.05 & 0.08 & 0.07 & $<0.1$ \\
\hline $\begin{array}{l}\text { Negra } \\
\text { viscosity }\end{array}$ & 8 & - & 12 & 11 & 11 & 11 & 12 & & $3-20$ \\
\hline $\begin{array}{c}\text { Storage } \\
\text { stability } \\
\text { (1d) } \\
\%\end{array}$ & 0.8 & - & 2.8 & 2.9 & 1.9 & 1.5 & 1.2 & 1.4 & $<1.0$ \\
\hline $\begin{array}{c}\text { Storage } \\
\text { stability } \\
(5 d), \\
\%\end{array}$ & 4.4 & & 12.7 & 11.5 & 7.8 & 4.9 & 5.1 & 4.9 & $<5.0$ \\
\hline $\begin{array}{l}\text { Low } \\
\text { temperatu } \\
\text { re storage } \\
\text { stability } \\
\left(-5^{\circ} \mathrm{C}\right)\end{array}$ & qualified & - & $\begin{array}{c}\text { Unqualifi } \\
\text { ed }\end{array}$ & $\begin{array}{c}\text { Unqualifie } \\
\text { d }\end{array}$ & $\begin{array}{l}\text { Have a } \\
\text { lump }\end{array}$ & qualified & $\begin{array}{l}\text { Coarse- } \\
\text { grained } \\
\text { particles }\end{array}$ & qualified & \\
\hline $\begin{array}{l}\text { Mixing } \\
\text { with } \\
\text { cement }\end{array}$ & good & - & $\begin{array}{c}\text { commonl } \\
\mathrm{y}\end{array}$ & commonly & $\begin{array}{c}\text { commonl } \\
\mathrm{y}\end{array}$ & good & preferably & good & \\
\hline \multicolumn{10}{|c|}{ Properties of evaporation residue } \\
\hline content & & - & 49.3 & 52.4 & 62.7 & 64.2 & 62.3 & & $>60$ \\
\hline $\begin{array}{l}\text { Softening } \\
\text { point } /{ }^{\circ} \mathrm{C}\end{array}$ & & - & 78.2 & 79.7 & 70.1 & 71 & 69.5 & & $>53$ \\
\hline $\begin{array}{c}5^{\circ} \mathrm{C} \text { Ductil } \\
\text { ity } / \mathrm{cm}\end{array}$ & & - & - & - & 29 & 30 & 30 & & $>20$ \\
\hline
\end{tabular}

It can be seen from Table 9 that the two emulsifier mixtures can not meet the emulsification requirements of modified asphalt with $7 \%$ SBS content, although the addition of Peral600 greatly improves the emulsifying ability of the emulsified system. SBS modified asphalt with $7 \%$ content has high viscosity and is difficult to emulsify, and 5\% SBS modified asphalt can be emulsified basically, but its stability is not very good, indicating that $5 \%$ content is the limit of SBS modified asphalt emulsification.

When Peral600 dosage is $1.0 \%$ of the total emulsifier dosage, SBS modified asphalt can be emulsified well, and other performance indicators can meet the requirements; when the Peral600 dosage 
continues to increase, the emulsification effect will become worse, indicating that there is an optimum proportion of multiple emulsifiers.

It can be seen from Table 9 that the emulsifying effect of modified asphalt with 5\% SBS content is only barely qualified when the emulsifier dosage is $1.8 \%$; the effect is not obvious when the emulsifier dosage is increased, and the optimum emulsifier dosage is $1.8 \%$ considering the economic benefits.

\subsection{SBS latex modified asphalt}

In order to further compare the preparation methods of SBS modified emulsified asphalt, SBS modified emulsified asphalt was prepared from SBS latex and SK90\# base asphalt, which were commonly used in the market[11]. The amount of latex added in the test is $3 \%$ $\sim 6 \%$, and the modified emulsified asphalt is shown in Table 10.

Table 10 Performance index of modified emulsified asphalt

Evaporation residue

\begin{tabular}{|c|c|c|c|c|c|c|}
\hline Test project & JTG standard & $1 \#(3 \%)$ & $2 \#(4 \%)$ & $3 \#(5 \%)$ & $4 \#(6 \%)$ & $5 \%$ SBS \\
\hline Ion charge & + & + & + & + & + & + \\
\hline Residue on sieve $\%$ & $\leq 0.1$ & 0.02 & 0.01 & 0.01 & 0.02 & 0.05 \\
\hline Negra viscosity $\left(25^{\circ} \mathrm{C}\right)$ & $3 \sim 30$ & 9.4 & 8.3 & 7.2 & 5.2 & 11 \\
\hline storage stability（1d）\% & $\leq 1$ & 0.55 & 0.79 & 0.93 & 1.1 & 1.5 \\
\hline \multirow{4}{*}{$\begin{array}{c}\text { Solid content }(\%) \\
\text { softening point } /{ }^{\circ} \mathrm{C} \\
\text { solubility }(\%)\end{array}$} & $\geq 60$ & 71.8 & 71.1 & 70.8 & 70.2 & 64.2 \\
\hline & $\geq 53(60)$ & 57.1 & 62.4 & 64.8 & 67.9 & 71 \\
\hline & $\geq 97.1$ & 98.4 & 98.3 & 98.5 & 98.9 & 99.1 \\
\hline & & & & & & \\
\hline Ductility $\left(5^{\circ} \mathrm{C}\right) / \mathrm{cm}$ & $\geq 20 \quad(40)$ & 25.5 & 32.2 & 36.5 & 40.7 & 30 \\
\hline
\end{tabular}

Note: the values in brackets are recommended values in alpine regions.

Jinan University(Natural Science \& Medicine

\section{The results and analysis}

(1) The emulsified asphalt produced by this equipment was modified by latex with good overall quality and good ductility.

(2) $4 \%$ SBS latex can make the emulsified asphalt meet the standard requirements, but only $6 \%$ SBS latex can get better road performance.

(3) The SBS modified emulsified asphalt prepared by this method meets the requirement of highly cold area although its softening point is still low.

\section{References}

1.Cai Hongmei,Zhang Yuzhen,Wang Tao. Study on the stability of SBS latex modified asphalt emulsion[J]. Petroleum Asphalt,2008,22(3):20-23.(in chinese)

2. Xu Shifa,Luo Xiaohui,Sun Zhongge. Performance Evaluation and Comparison of SBS Emulsion Warm Mixture and Hot SBS Modified Asphalt

Mixture[J]. Journal of Beijing University of Civil Engineering and Architecture,2008,24(2):25-29. (in chinese)

3. WU Kuang-huai,LI Yan-feng,YANG Guo-liang,LING Hong-jie. Experimental research on the cold recycled asphalt mixtures with emulsified asphalt[J]. Journal of
Edition),2008,29(3):281-285. (in chinese)

4. SHA Ai-min, WANG Zhen-jun. Microstructure of mastics-aggregate interface in cement emulsified asphalt concrete[J]. Journal of Chang' an University(Natural Science Edition),2008,28(4): 1-6. (in chinese)

5. XIAO Jing-jing,ZHENG Nan-xiang,SONG Zhe-yu. Study on Effect of Emulsifier on Modified Emulsified Asphalt and Its Mechansim[J]. Journal of Zhengzhou University(Engineering Science),2008,29(3):5-9. (in chinese)

6. WU Chao-fan,ZENG Meng-lan,ZHONG Mengwu,XIAO Jie. Experimental Study of the Design Method for Cold Recycled Mixture Using Asphalt Emulsion[J]. Journal of Hunan University(Natural Sciences),2008,35(8):19-23. (in chinese)

7. LI Zihua. Application of SBR modified emulsified asphalt as viscosified oil in engineering $[\mathrm{J}]$. Journal of Highway and Transportation Research and

Development,2000,11(3): 10-12.

(in chinese)

8. Xia Chaobin, Ma Bo. Development and Application Situation of Emulsified Asphalt at Home and Abroad[J]. Chemical Engineering of Oil \& Gas,2000,29(2) : 88$91+52$. (in chinese) 
9.Wang T, Huang X, Zhang Y. Application of Hansen

Solubility Parameters to Predict Compatibility of SBS-

Modified Bitumen[J].ournal of Materials in Civil

Engineering.2010, 22(8): 773-778.

10.Lu X, Isacsson U, Ekblad J: Phase Separation of SBS

Polymer Modified Bitumens[J]. Journal of Materials in

Civil Engineering.1999, 11(1): 51-57. 